\title{
Effect of active immunization against oestrogens on plasma gonadotrophins in the ewe and the response to synthetic oestrogen or LH
}

\author{
H. C. Pant*, Hilary Dobson and W. R. Ward \\ Department of Veterinary Clinical Studies, University of Liverpool, \\ 'Leahurst', Neston, Wirral, L64 7TE, U.K.
}

\begin{abstract}
Summary. Immunization against oestrogen resulted in elevated LH concentrations, in the form of a pulsatile release, which rose from 3 to as much as $41 \mathrm{ng} / \mathrm{ml}$ approximately every $1.5 \mathrm{~h}$, even in the presence of high plasma progesterone concentrations. Elevated FSH concentrations showed only minor oscillations without consistent synchrony to the LH pulses. Injection of $250 \mu \mathrm{g}$ stilboestrol did not abolish the LH pulses but in 2 out of 8 ewes FSH was initially lowered. Injection of $1 \mathrm{mg}$ stilboestrol abolished the $\mathrm{LH}$ pulses within $11 \mathrm{~h}$ and decreased FSH values in 2 out of 4 ewes. Between 16 and $35 \mathrm{~h}$ after injection there was a large increase in LH and FSH concentrations. Thus, in the ewe, the tonic secretion of $\mathrm{LH}$ and FSH is controlled by a negative feedback action of oestrogen, and diethylstilboestrol will exert both positive and negative feedback effects on both gonadotrophins, depending upon dose. Infusion of $\mathrm{LH}$ was unable to alter the frequency or height of the LH pulses, thereby excluding regulation of the LH pulses by a short feedback mechansim.
\end{abstract}

\section{Introduction}

Many studies have provided ample evidence to indicate that the ovarian oestradiol secretion at the time of oestrus triggers the release of LH and FSH in the cyclic ewe by a positive feedback action (Goding et al., 1969; Pant, Hopkinson \& Fitzpatrick, 1977) and that the administration of oestradiol evokes a discharge of both gonadotrophins in the anoestrous ewe (Jonas et al., 1973; Pant \& Ward, 1974).

The demonstration of a marked rise in the plasma $\mathrm{LH}$ of ewes after ovariectomy provided indirect evidence for the negative feedback effect of gonadal steroid hormones on LH release (Niswender, Roche, Foster \& Midgley, 1968; Roche, Foster, Karsch \& Dziuk, 1970). Scaramuzzi, Tillson, Thorneycroft \& Caldwell (1971) reported an initial negative feedback effect of oestradiol benzoate on plasma LH concentrations in ovariectomized ewes, and Brown, Cumming, Goding \& Hearnshaw (1972) observed a fall in the elevated plasma LH concentrations of ovariectomized ewes following prolonged infusion of oestradiol.

In none of the above studies was the concentration of plasma FSH measured. The present study was therefore designed to gain further insight into both the negative and positive feedback effects of oestradiol on $\mathrm{LH}$ and FSH secretion in ewes which were actively immunized against oestrogen.

\section{Materials and Methods}

\section{Animals}

In September, 5 mature Clun Forest ewes were immunized against oestrogen with a conjugate of oestradiol-17 $\beta$-hemisuccinate with bovine serum albumin after each had exhibited one normal

* Present address: Department of Gynaecology \& Reproduction, Veterinary College, Mathura, U.P., India. 
oestrous cycle. The immunization schedule consisted of three subcutaneous injections of $2 \mathrm{mg}$ conjugate emulsified in $1 \mathrm{ml}$ Freund's complete adjuvant at 21-day intervals (Days 0, 21 and 42), followed by similar 'booster' injections throughout the following year on Days 109, 127, 158, 218, 290, 340 and 376. Each experiment took place 2 weeks after an injection of the immunogen. Each ewe was tested with a vasectomized ram for signs of oestrus. The ewes were housed indoors in individual pens and indwelling jugular venous catheters were inserted $25 \mathrm{~h}$ before each sampling period.

\section{Experimental design}

Experiment I. In January, on Day 123 after immunization began, the ewes were injected with $0.5 \mathrm{ml}$ arachis oil and bled every $2 \mathrm{~h}$ for $36 \mathrm{~h}$ without further treatment. In this, and subsequent experiments, $5 \mathrm{ml}$ blood were collected into heparinized syringes and centrifuged and the plasma was stored at $-15^{\circ} \mathrm{C}$ until analysis.

Experiment 2. On Day 141, blood was collected every $15 \mathrm{~min}$ for $8 \mathrm{~h}$ from each ewe, except No. 73 , to investigate the short-term changes in plasma gonadotrophin concentration.

Experiment 3. On Day 172 the ewes were injected i.m. with a pharmacological dose of stilboestrol dipropionate (May \& Baker Ltd), $250 \mu \mathrm{g}$ in $0.5 \mathrm{ml}$ arachis oil, and bled every $2 \mathrm{~h}$ for $48 \mathrm{~h}$.

Experiment 4. On Day 232 (April) the ewes were injected i.m. with $1 \mathrm{mg}$ oestradiol-17ß (Koch Light) and bled every $2 \mathrm{~h}$ for $36 \mathrm{~h}$.

Experiment 5. Three of the ewes (Nos 17, 78 and 80) were treated on Day 304 with $0.5 \mathrm{ml}$ arachis oil i.m. followed $4 \mathrm{~h}$ later by an i.m. injection of $250 \mu \mathrm{g}$ stilboestrol dipropionate. Blood was collected every $15 \mathrm{~min}$ for $12 \mathrm{~h}$ after the arachis oil injection.

Experiment 6. On Day 3904 ewes (Nos Y5, 17, 70 and 80), were bled at 15-min intervals for $4 \mathrm{~h}$ then injected i.m. with $1 \mathrm{mg}$ stilboestrol dipropionate in arachis oil $(0 \mathrm{~h})$. Blood sampling continued every $15 \mathrm{~min}$ for $4 \mathrm{~h}$ and every $2 \mathrm{~h}$ for the next $48 \mathrm{~h}$ with a $2-\mathrm{h}$ period of 15 -min sampling interspersed at 11,23 and $35 \mathrm{~h}$.

Experiment 7. On Day 354, blood was collected (control period) every $15 \mathrm{~min}$ for $4 \mathrm{~h}$ from 4 ewes (Nos Y5, 17, 78, 80) and was followed by an i.v. infusion of ovine LH (NIH-LH-S16) at a rate of $30 \mathrm{mg} / \mathrm{h}$ for $4 \mathrm{~h}$. Blood sampling was continued every $15 \mathrm{~min}$ from a catheter in the contralateral jugular vein.

\section{Hormone radioimmunoassays}

Oestrogen. The potency of the oestrogen antisera was estimated on Days 123 and 232 after the start of immunization in a liquid-phase system (Pant et al., 1977) and the results are given in Table 1. The inter- and intra-assay coefficients of variation were 12.6 and $9.7 \%$ respectively. The crossreactions of the antisera from each ewe were estimated as described by Abraham (1969); the crossreactions ranged from 58 to $77 \%$ for oestrone and from 49 to $69 \%$ for oestradiol- $17 \alpha$.

Table 1. Dilutions of serum samples from ewes immunized against oestrogen which bound $50 \%$ of 10000 c.p.m. of ${ }^{3} \mathrm{H}$-labelled oestradiol

\begin{tabular}{llc}
\hline & \multicolumn{2}{c}{ Titre } \\
\cline { 2 - 3 } Ewe & Exp. 1 & Exp. 4 \\
\hline 73 & $1: 4000$ & $1: 10000$ \\
Y5 & $1: 17000$ & $1: 37000$ \\
78 & $1: 24000$ & $1: 42000$ \\
80 & $1: 29000$ & $1: 40000$ \\
17 & $1: 34000$ & $1: 62000$ \\
\hline
\end{tabular}


Progesterone. The first sample from each ewe in each experiment was analysed for progesterone by the unmodified method described and verified by Pant $e$ al. (1977). The progesterone antibody was raised against progesterone-6 $\alpha$-(carboxymethylene) thio-ether-bovine serum albumin and showed only $2 \%$ cross-reaction with $20 \alpha$-hydroxypregn-4-en-3-one and $4 \%$ with $17 \alpha$-hydroxyprogesterone. The sensitivity of the method was $25 \mathrm{pg} / 0.5 \mathrm{ml}$ and the inter- and intra-assay coefficients of variation were 10.6 and $9.7 \%$ respectively.

$L H$ and FSH. These hormones were measured in every plasma sample by the unmodified methods described and verified by Pant et al. (1977). The anti-ovine LH antibody (GDN-15) was raised in rabbits by Dr G. D. Niswender and had no significant cross-reaction with other pituitary hormones. Purified ovine LH (LER-1056-C2) was used as the ${ }^{125}$ I-labelled preparation. The sensitivity of the method was $<200 \mathrm{pg} / 0.2 \mathrm{ml}$ and the inter- and intra-assay coefficients of variation were 14.3 and $8.8 \%$ respectively. The plasma results are expressed in ng equivalents of NIH-LH-S $16 / \mathrm{ml}$. The anti-ovine FSH antibody was raised in rabbits by Dr J. C. Hendrick and had $30 \%$ cross-reaction with TSH and $5 \%$ with $\mathrm{LH}$. Absorbing the antiserum with $500 \mathrm{ng}$ ovine TSH and $\mathrm{LH}$ made no significant difference to the plasma results. Rat FSH (NIH-FSH-RP1) was used as the ${ }^{125}$ I-labelled preparation. The sensitivity of the method was $10 \mathrm{ng} / 0.2 \mathrm{ml}$ with inter- and intra-assay coefficients of variation of 7.8 and $7.0 \%$ respectively.

\section{Results}

\section{Experiment 1}

The gonadotrophin pattern obtained in all the ewes is exemplified by that of Ewe Y5 (Text-fig. 1a). The mean ( \pm s.e.m.) hormone values in all 5 ewes were $8.3 \pm 0.99 \mathrm{ng} \mathrm{LH} / \mathrm{ml}$ and $124 \pm 6.02 \mathrm{ng}$ $\mathrm{FSH} / \mathrm{ml}$ and these were significantly higher (Student's $t$ test, $P<0.01$ ) than the values observed in intact ewes during anoestrus $(2 \cdot 1 \pm 0 \cdot 13 \mathrm{ng} \mathrm{LH} / \mathrm{ml}$ and $37 \pm 2 \cdot 6 \mathrm{ng} \mathrm{FSH} / \mathrm{ml}, \mathrm{N}=4)$ and during the luteal phase of the oestrous cycle $(2.6 \pm 0.09 \mathrm{ng} \mathrm{LH} / \mathrm{ml}$ and $62 \pm 2.8 \mathrm{ng} \mathrm{FSH} / \mathrm{ml}, \mathrm{N}=4)$. The progesterone concentrations at the beginning of this experiment were $0.4,13.6,0.5,5.5$ and $0.9 \mathrm{ng} / \mathrm{ml}$ for Ewes Y 5, 17, 73, 78 and 80 respectively.

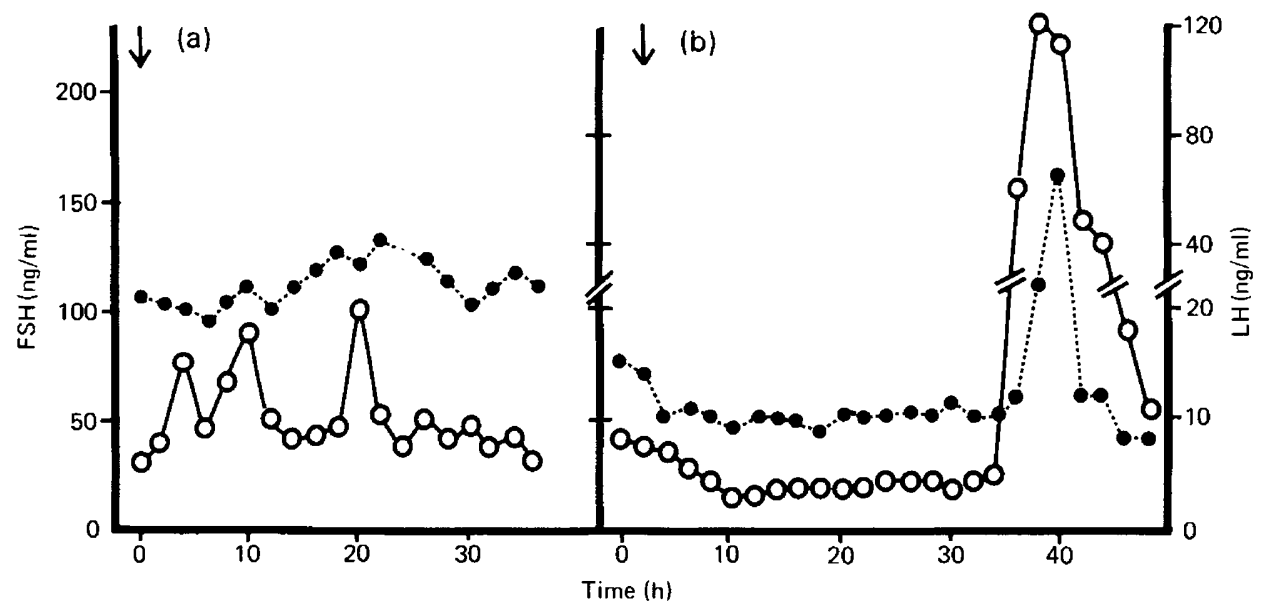

Text-fig. 1. Plasma LH (0) and FSH (e) concentrations in Ewe Y5 after i.m. injection (arrow) of (a) arachis oil (Exp. 1) and (b) $250 \mu \mathrm{g}$ stilboestrol dipropionate (Exp. 3).

\section{Experiment 2}

Frequent blood sampling revealed a pulsatile pattern of plasma $\mathrm{LH}$ release (Text-fig. 2); there was an abrupt and significant rise (one-way analysis of variance, $P<0.001$ ) in plasma LH from nadir to peak within a period of $15 \mathrm{~min}$. The interval between one peak and the next varied within 
and between ewes, ranging from 75 to $100 \mathrm{~min}$. The magnitude of the peaks ranged from 8.6 to $41.5 \mathrm{ng} / \mathrm{ml}$ with baseline values between 3.9 and $5.1 \mathrm{ng} / \mathrm{ml}$. In contrast the concentration of plasma FSH did not change in such a pulsatile manner but showed minor oscillations without any consistent synchrony with LH pulses. The differences between maximum and minimum values of FSH were not significant. Plasma concentrations of progesterone were $0.5,10 \cdot 1,0.5$ and $5.5 \mathrm{ng} / \mathrm{ml}$ for Ewes Y5, 17,78 and 80 respectively at the start of sampling.

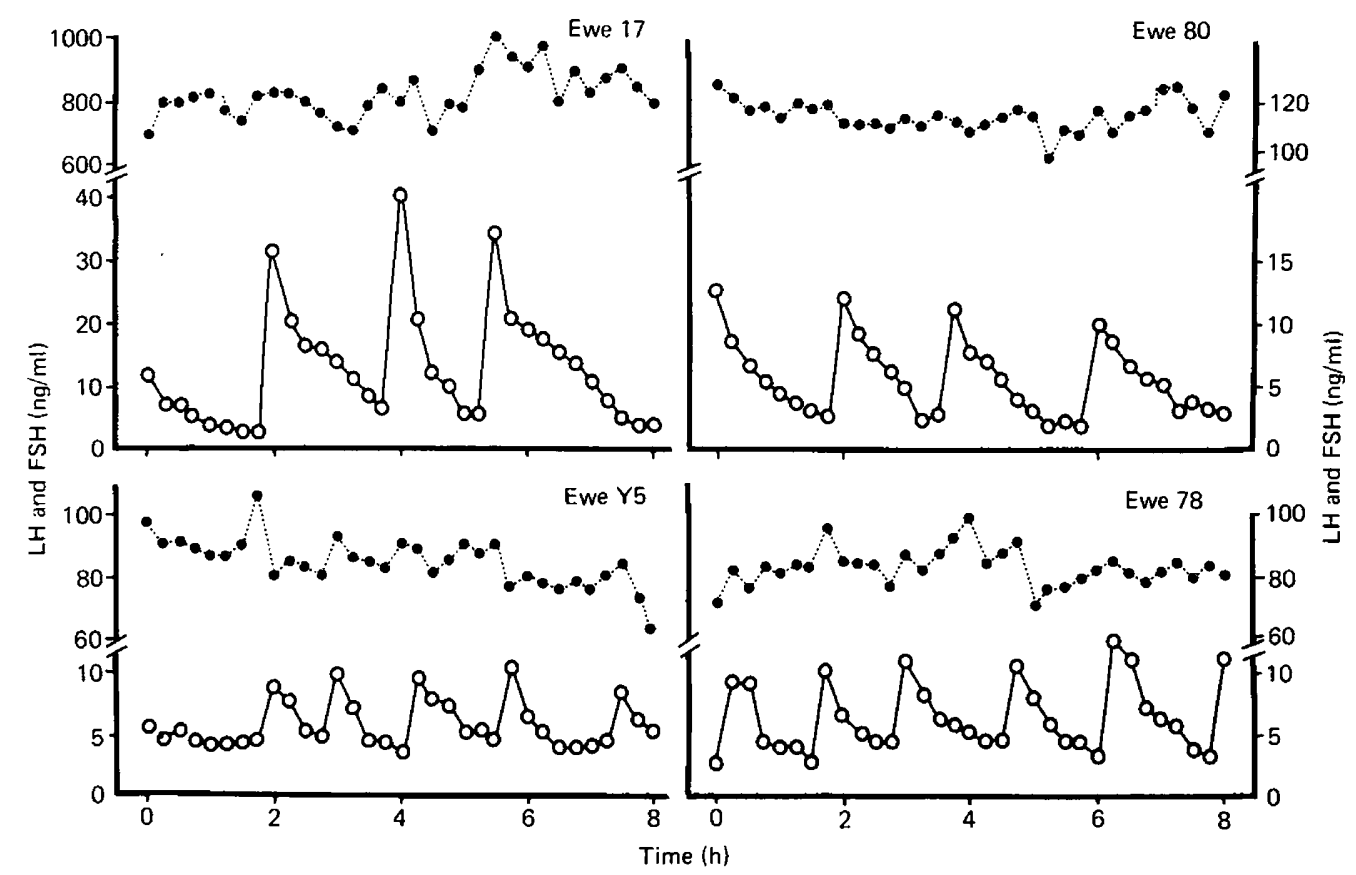

Text-fig. 2. LH (0) and FSH (•) concentrations in ewes immunized against oestrogen in plasma samples collected at 15-min intervals (Exp. 2).

\section{Experiment 3}

An example of the gonadotrophin pattern obtained from sampling every $2 \mathrm{~h}$ after injection of $250 \mu \mathrm{g}$ stilboestrol dipropionate is shown in Text-fig. 1(b). There was initially a decrease in both $\mathrm{LH}$ and FSH concentrations but this was not significant $(P<0 \cdot 1$, Student's paired $t$ test). Three of the 5 ewes also showed a marked elevation in plasma gonadotrophins beginning between 18 and $36 \mathrm{~h}$ $(23 \cdot 3 \pm 6 \cdot 7$, s.e.m.) after the injection of stilboestrol and reaching peak values of $82-130(114 \pm 13 \cdot 1)$ $\mathrm{ng} \mathrm{LH} / \mathrm{ml}$ and 135-160 (148.3 \pm 5.92$) \mathrm{ng} \mathrm{FSH} / \mathrm{ml}$ between 20 and $38 \mathrm{~h}$. The rise lasted for 8 to $12 \mathrm{~h}$ $(10 \pm 0.92 \mathrm{~h})$. The progesterone concentrations were $1 \cdot 7,0.1 \mathrm{and} 0.4 \mathrm{ng} / \mathrm{ml}$ in the 3 responding ewes (Nos Y5, 73 and 78 respectively) and $7 \cdot 3$ and $5 \cdot 0 \mathrm{ng} / \mathrm{ml}$ in Ewes 17 and 80.

\section{Experiment 4}

In contrast to the effect of the synthetic oestrogen, no decrease or later elevation in the circulating gonadotrophins was produced by injection of oestradiol-17 $\beta$. The initial concentration of progesterone was $0 \cdot 5,10 \cdot 1,0 \cdot 5,0.6$ and $5 \cdot 5 \mathrm{ng} / \mathrm{ml}$ for Ewes Y5, 17, 73, 78 and 80 respectively.

\section{Experiment 5}

In the $8 \mathrm{~h}$ after the injection of $250 \mu \mathrm{g}$ stilboestrol dipropionate in oil, the pulsatile $\mathrm{LH}$ discharge was not abolished, although, as shown in Table 2, there was a non-significant decrease in both the 


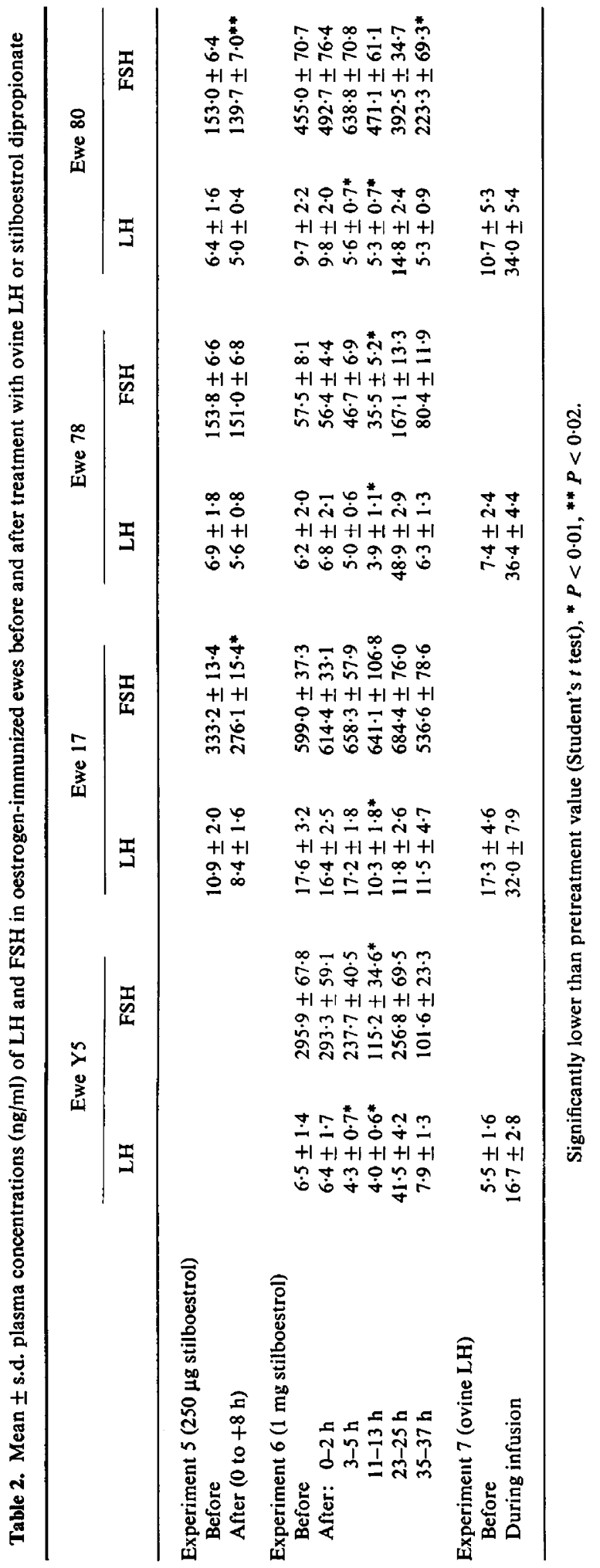


mean LH concentration and the standard deviation (Student's paired $t$ test). The frequency of LH pulses was not affected. However, in Ewes 17 and 80 the mean plasma FSH concentration was significantly reduced $(P<0.01$ and 0.02 respectively). Plasma concentrations of progesterone at the start of the experiment were $3 \cdot 5,1 \cdot 1$ and $0.6 \mathrm{ng} / \mathrm{ml}$ for Ewes 17, 78 and 80 .

\section{Experiment 6}

For the first $3 \mathrm{~h}$ after injection of $1 \mathrm{mg}$ stilboestrol dipropionate in oil, the plasma LH pulses persisted in all 4 ewes (Table 2) and their frequency was sustained. Thereafter the peak heights diminished and by $11 \mathrm{~h}$ after injection the pulses were absent and did not reappear until after a very large increase in $\mathrm{LH}$, ranging between 14.8 and $48.9 \mathrm{ng} / \mathrm{ml}$, in Ewes 80 , $\mathrm{Y} 5$ and 78 . This raised concentration was sustained in the 3 ewes between 16 and $35 \mathrm{~h}$ after injection; it was not detected at all in Ewe 17. In Ewes Y5 and 78 the plasma concentration of FSH was reduced by $+3 \mathrm{~h}$ with a further decline over the next $8 \mathrm{~h}$; in these two animals large increases in FSH also occurred concurrently with $\mathrm{LH}$ at about $+24 \mathrm{~h}$. Plasma FSH did not alter significantly throughout the experiment in Ewe 17 and was only significantly lower in Ewe 80 at $+35 \mathrm{~h}$. Initial plasma concentrations of progesterone were $0 \cdot 1,0 \cdot 2,0 \cdot 1$ and $0 \cdot 1 \mathrm{ng} / \mathrm{ml}$ for Ewes $\mathrm{Y} 5,17,78$ and 80 respectively.

\section{Experiment 7}

Before infusion of $\mathrm{LH}$ there was a pulsatile variation in $\mathrm{LH}$ concentration as described in Exp. 2. During the $\mathrm{LH}$ infusion the increase in mean LH concentration ranged from 2-fold to 5-fold, in the 4 ewes compared to the control period (Table 2). However, the standard deviation did not decrease, i.e. the pulsatile release of $\mathrm{LH}$ was not diminished by the higher circulating $\mathrm{LH}$ concentrations. The frequency of the pulses was not affected by the LH infusion. The initial plasma progesterone concentrations were $0 \cdot 4,1 \cdot 0,2 \cdot 1$ and $1 \cdot 6 \mathrm{ng} / \mathrm{ml}$ for Ewes $\mathrm{Y} 5,17,78$ and 80 respectively.

\section{Discussion}

Active immunization against oestrogen appears to remove the suppression on the hypothalamicpituitary axis which is exerted, at least partly, by oestrogens. The pulsatile pattern of plasma LH observed in Exp. 2 indicates that the elevated mean concentration found during Exp. 1 was not due to a continuous high rate of secretion but represents an integration of discrete discharges of LH from the pituitary of varied but high magnitude. In this respect immunization against oestrogen mimics the castration effect reported in other species (ewe: Butler, Malvern, Willett \& Bolt, 1972; Reeves, O'Donnell \& Denorscia, 1972; Diekman \& Malvern, 1973; monkey: Dierschke, Bhattacharya, Atkinson \& Knobil, 1970).

Our results show that the upper part of the descending limb of the LH pulses has a steeper slope than does the lower end. The half-life of LH calculated from the regression estimates of the upper segment of 11 descending limbs averaged $28.3 \pm 1.02 \mathrm{~min}$ and is similar to that previously reported $(28.6 \mathrm{~min}$ ) for intact ewes (Geschwind \& Dewey, 1968). However, the half-life calculated from estimates of whole descending limbs was $45.5 \mathrm{~min}$, suggesting a sustained rather than abrupt release of LH from the pituitary at each pulse. Alternatively, it is an indication that the LH pulses may be superimposed on a high but relatively constant secretion as suggested earlier for ovariectomized monkeys (Yamaji, Dierschke, Bhattacharya \& Knobil, 1972). An assumption implicit in this suggestion is that immunization does not alter the metabolic clearance rate of LH.

The relatively constant pattern of FSH concentration without pulses could be due, at least in part, to the longer half-life of ovine FSH ( $72 \mathrm{~min}$; Kragt \& Cons, 1973), to a differential effect of active immunization against oestrogen on the response of pituitary gonadotrophins to the gonadotrophin releasing factor, or to there being two separate releasing mechanisms regulating the secretion of two gonadotrophins.

As expected, after injection of oestradiol-17 $\beta$ there was no alteration in the pattern of gonado- 
trophins, presumably because of neutralization of the exogenous hormone by the high titre of antibodies to oestrogen. The synthetic oestrogen, stilboestrol dipropionate, was chosen to investigate the effect of oestrogen replacement because it would not cross-react with the antibodies present. The lower dose $(250 \mu \mathrm{g})$ did not have any significant short-term effect $(+8 \mathrm{~h})$ on the LH pulses in Exps 3 and 5, but the higher dose ( $1 \mathrm{mg}$ ) lowered the mean LH concentration significantly by $+11 \mathrm{~h}$ in all 4 ewes, demonstrating that the negative feedback system was still operative in oestrogenimmunized ewes. However, from our limited results it is not possible to distinguish between the effects of dose and time. This latter relationship has been shown in ovariectomized ewes after treatment with oestradiol: an infusion of $0.1 \mu \mathrm{g} / \mathrm{h}$ in saline took 3-4 weeks to reduce $\mathrm{LH}$ concentrations to pre-ovariectomy values (Brown et al., 1972), whereas a single injection of $25 \mu \mathrm{g}$ oestradiol benzoate in alcohol or $100 \mu \mathrm{g}$ oestradiol in oil reduced LH concentrations within $4 \mathrm{~h}$ (Davis \& Borger, 1974; Howland \& Palmer, 1973). In our experiments there was a variable response of plasma FSH to stilboestrol dipropionate. This could again have been a dose effect: only 2 of the 8 ewes treated with $250 \mu \mathrm{g}$ and 2 of the 4 treated with $1 \mathrm{mg}$ had significantly lower plasma FSH values by $+8 \mathrm{~h}$. The independence of the FSH decrease in concentration from that of $\mathrm{LH}$ could be due to a differential effect of oestrogen on the pituitary content and turnover times of the two gonadotrophins, or to the existence of a separate FSH releasing mechansim.

A positive feedback effect after synthetic oestrogen was also demonstrated in Exps 3 and 6 . The $\mathrm{LH}$ concentration began to rise $16.6 \pm 1.0 \mathrm{~h}$ after the injection of $1 \mathrm{mg}$ stilboestrol dipropionate in oil to ewes immunized for 390 days (Exp. 6) compared to a rise $23.3 \pm 6.9 \mathrm{~h}$ after $250 \mu \mathrm{g}$ stilboestrol dipropionate in oil to ewes immunized for 172 days (Exp. 3). Reeves, Beck \& Nett (1974) reported the same time interval to gonadotrophin surges after different doses of oestradiol in alcohol given to anoestrous ewes. However, Brown et al. (1972) reported different intervals in the response to exogenous oestradiol of ewes which had recently been ovariectomized than in those ovariectomized 120 days previously. These observations suggest that the difference in the time lag to the induced gonadotrophin surges found in Exps 3 and 6 could be due to an alteration in the sensitivity of the hypothalamic-pituitary axis during the absence of oestrogen and not simply to the different doses of stilboestrol dipropionate used.

The lack of positive response in the 2 ewes in Exp. 3 could be associated with the high plasma progesterone concentrations in these animals $(7 \cdot 3$ and $5 \mathrm{ng} / \mathrm{ml}$ ), because others (Pelletier \& Signoret, 1969; Scaramuzzi et al. 1971; Pant \& Ward, 1974) have reported that progesterone can block the stimulatory effect of oestrogen on gonadotrophin release. The positive response to oestrogen in one ewe (Y5), despite a plasma progesterone of $1.78 \mathrm{ng} / \mathrm{ml}$, confirms our earlier conclusion (Pant \& Ward, 1974) that the inhibitory effect of progesterone can be overcome by a high dose of oestrogen.

The immunized ewes did not exhibit behavioural oestrus during the breeding season. The progesterone concentrations showed considerable variation ranging from 0.55 to $13.6 \mathrm{ng} / \mathrm{ml}$. High values were also observed in samples taken during the non-breeding season when values of $<0.2$ $\mathrm{ng} / \mathrm{ml}$ are expected in untreated ewes, but the pulsatile mode of LH secretion was maintained even in the presence of these high concentrations of plasma progesterone.

The inability of an infusion of ovine $\mathrm{LH}$ to abolish the pulsatile pattern of endogenous $\mathrm{LH}$ would suggest that a 'short' feedback mechanism of pituitary secretion on hypothalamic activity is not the regulatory mechanism causing the sudden decreases in plasma LH concentration. David, Fraschini \& Martini (1966) showed that median eminence implants of LH in the rat lowered plasma LH values; possibly a high enough hypothalamic concentration of $\mathrm{LH}$ was not achieved by our infusion. However, the concept of a short-feedback mechanism is hard to correlate with the high concentration of $\mathrm{LH}$ at the nadir of a pulse compared to normal luteal phase concentrations. If a short feedback mechansim did exist, the basal concentration of $\mathrm{LH}$ could not rise in immunized or castrated animals.

The present results do not reveal the mechanism which regulates the pulsatile release of $\mathrm{LH}$ in immunized ewes. Intermittent signals from the central nervous system may trigger a periodic release of gonadotrophin releasing factor, as suggested from studies in ovariectomized monkeys in which pulsatile $\mathrm{LH}$ surges were abolished by $\alpha$-adrenergic blocking agents (Bhattacharya, Dierschke, Yamaji \& Knobil, 1972). 
We are grateful to the Wellcome Trust (H.C.P.) and the Animal Health Trust (H.D.) for financial support; to Dr R. B. Snook, Dr L. E. Reichert, Jr, Professor H. R. Lindner, Dr J. C. Hendrick and NIAMDD for provision of radioimmunoassay materials; and Professor R. J. Fitzpatrick for facilities and encouragement.

\section{References}

Abraham, G.E. (1969) Solid-phase radioimmunoassay of estradiol-173. J. clin. Endocr. Metab. 29, 866-870.

Bhattacharya, A.N., Dierschke, D.J., Yamajt, T. \& KNOBIL, E. (1972) The pharmacological blockade of the circhoral mode of LH secretion in the ovariectomized Rhesus monkey. Endocrinology 90, 778-786.

Brown, J.M., Cumming, I.A., Goding, J.R. \& HearnSHAW, H. (1972) Control of baseline levels of luteinizing hormone in the ewe. J. Reprod. Fert. 28, 134-135.

Butler, W.R., Malvern, P.V., Willett, L.B. \& Bolt, D.J. (1972) Patterns of pituitary release and cranial output of LH and prolactin in ovariectomized ewes. Endocrinology 91, 793-801.

David, M.A., Fraschini, F. \& Martini, L. (1966) Control of $\mathrm{LH}$ secretion: role of a "short" feedback mechanism. Endocrinology 78, 55-60.

Davis, S.L. \& Borger, M.L. (1974) Dynamic changes in plasma prolactin, luteinizing hormone and growth hormone in ovariectomized ewes. J. Anim. Sci. 38, 795-802.

Diekman, M.A. \& Malvern, P.V. (1973) Effect of ovariectomy and estradiol on LH patterns in ewes. J. Anim. Sci. 37, 562-567.

Dierschke, D.J., Bhattacharya, A.N., Atkinson, L.E. \& KNoBIL, E. (1970) Circhoral oscillations of plasma LH levels in the ovariectomized Rhesus monkey. Endocrinology 87, 850-853.

Geschwind, I.I. \& DEWEY, R. (1968) Dynamics of luteinizing hormone (LH) secretion in the cycling ewe: a radioimmunoassay study. Proc. Soc. exp. Biol. Med. 129, 451-455.

Goding, J.R., Catt, K.J., Brown, J.M., Kaltenbach, C.C., Cumming, I.A. \& Mole, B.J. (1969) Radioimmunoassay for ovine luteinizing hormone. Secretion of luteinizing hormone during estrus and following estrogen administration in the sheep. Endocrinology 85, 133-142.

Howland, B.E. \& Palmer, W.M. (1973) Estrogeninduced changes in serum luteinizing hormone levels in ovariectomized ewes. Can. J. Anim. Sci. 53, $413-414$.

Jonas, H.A., Salamonsen, L.A., Burger, H.G., Chamley, W.A., Cumming, I.A., Findlay, J.K. \& Goding, J.R. (1973) Release of FSH after adminis- tration of gonadotrophin-releasing hormone or estradiol to the anoestrous ewe. Endocrinology 92, $862-865$.

KraGt, C.L. \& Cons, J. (1973) Radioimmunoassay of ovine FSH. J. Anim. Sci. 36, 908-913.

NisWender, G.D., Roche, J.F., Foster, D.L. \& Midgley, A.R. (1968) Radioimmunoassay of serum levels of luteinizing hormone during the cycle and early pregnancy in ewes. Proc. Soc. exp. Biol. Med. 129, 901-904.

PANT, H.C. \& WARD, W.R. (1974) Effect of intravenous infusion of oestradiol-17 $\beta$, with and without prior progesterone treatment, on the plasma luteinizing hormone and follicle-stimulating hormone concentrations in anoestrous ewes. J. Endocr. 61, v, Abstr.

Pant, H.C., Hopkinson, C.R.N. \& Fitzpatrick, R.J. (1977) Concentrations of oestradiol, progesterone, LH and FSH in the jugular venous plasma of ewes during the oestrous cycle. J. Endocr. 73, 247-255.

Pelletier, J. \& Signoret, J.P. (1969) Contrôle de la décharge de LH dans le sang par la progestérone et le benzoate d'oestradiol chez la brebis castrée. $C$. $r$. hebd. Séanc. Acad. Sci. Paris D 269, 2595-2598.

ReEves, J.J., BeCK, T.W. \& NetT, T.M. (1974) Serum FSH in anestrous ewes treated with $17 \beta$-estradiol. J. Anim. Sci. 38, 374-377.

ReEves, J.J., O'DONNell, D.A. \& Denorscia, F. (1972) - Effect of ovariectomy on serum luteinizing hormone (LH) concentrations in the anoestrous ewe. J. Anim. Sci. 35, 73-78.

Roche, J.F., Foster, D.L., Karsch, F.J. \& DziuK, P.J. (1970) Effect of castration and infusion of melatonin on levels of luteinizing hormone in sera and pituitaries of ewes. Endocrinology 87, 1205-1210.

Scaramuzzi, R.J., Tillson, S.A., Thorneycroft, I.H. \& Caldwell, B.V. (1971) Action of exogenous progesterone and estrogen on behavioural estrus and luteinizing hormone levels in the ovariectomized ewe. Endocrinology 88, 1184-1189.

Yamaji, T., Dierschke, D.J., Bhattacharya, A.N. \& KNOBIL, E. (1972) The negative feedback control by estradiol and progesterone of $\mathrm{LH}$ secretion in the ovariectomized Rhesus monkey. Endocrinology 90, 771-777.

Received 1 September 1977 